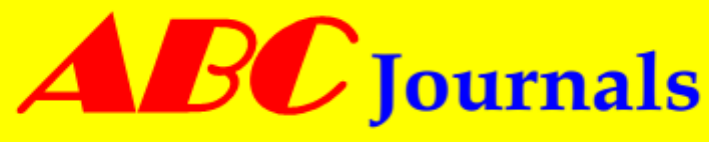

A new domain in research publishing

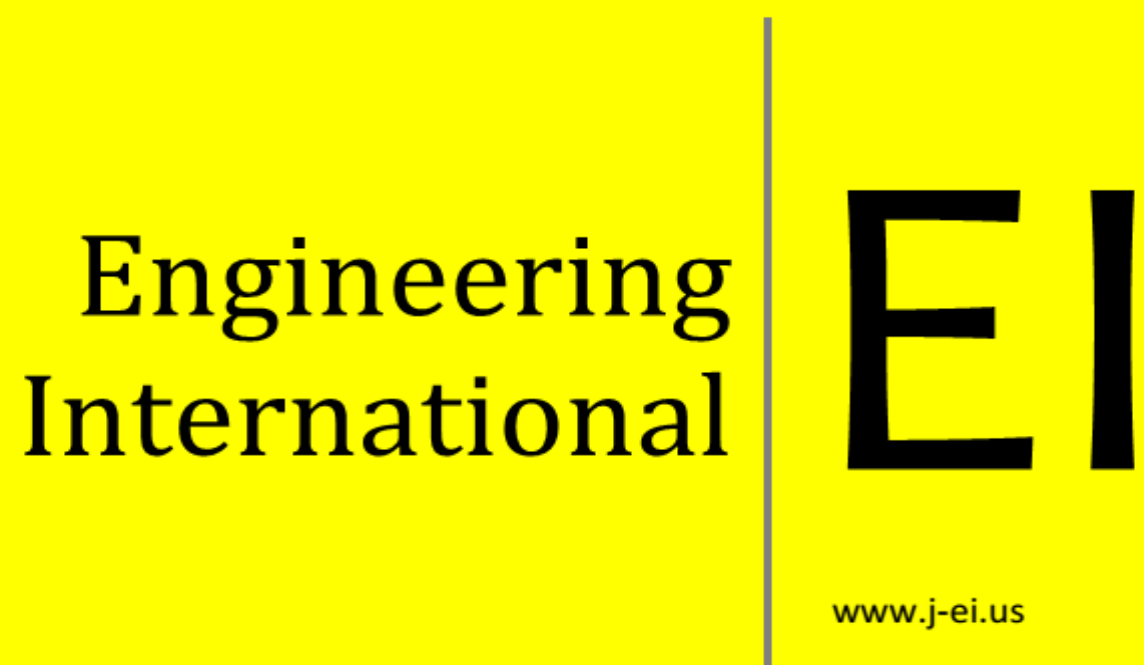

Asian Business Consortium 


\title{
The Relationship between Technological Factors and Inter-Organizational Information Systems Adoption by Universities in Kenya
}

\author{
Dr. Stephen Waithaka Titus ${ }^{1}$; Dr. Tom Kimani Mburu²; Dr. Julius Korir ${ }^{3}$; \& \\ Dr. Stephen Muathe ${ }^{4}$
}

${ }^{1}$ Lecturer, Communication and Information Technology Department, Kenyatta University, Kenya

${ }^{2}$ Manager, Training and Programs, Africa Economic Research Consortium, Nairobi, Kenya

${ }^{3}$ Lecturer, Economics Department, Kenyatta University, Kenya

${ }^{4}$ Lecturer, School of Business, Kenyatta University, Nairobi, Kenya

\begin{abstract}
Kenya government, in collaboration with other stakeholders involved in enhancing teaching and research in the learning institutions have constructed a terrestrial fiber-optic network that connects most institutions of higher learning to enable them integrate their facilities for the purpose of sharing resources. Despite these efforts, adoption of Inter-Organization Information Systems (IOIS) by universities in Kenya is far from being realized. This creates the need of finding out the relationship between the IOIS technological factors and the IOIS adoption. This study filled this gap by analyzing IOIS technological determinants of IOIS adopting in the universities in Kenya, given the mixed results from empirical evidence on IOIS adoption generally. A logit regression procedure was used to analyze the collected data. Two factors were found to hinder the IOIS adoption, while one factor was found to motivate IOIS adoption.
\end{abstract}

Keywords: IOIS adoption, Technological factors, Universities in Kenya

\section{INTRODUCTION}

Inter-organizational information systems (IOISs) are internet based information systems that electronically link organizations together to automate information flows between them Bakos (1991) and they include such technologies as electronic data interchange (EDI), Web-based EDI and Internet-based supply chain management systems, among others.

In Kenya, Inter-Organization Information system (IOIS) is mainly used in electronic commerce (Magutu et al., 2011) and in supply chain management though at low levels. By electronically linking organizations together, IOIS enables them to exchange business information, which makes them gain competitive advantage by increasing their bargaining power, and by raising the switching costs of trading partners (Johnston and Vitale, 1988). It also enhances organizational quality and timeliness of information (Silverman, 1990), improves efficiency (Kaefer and Bendoly, 2000) and enables entire supply chains to reduce wasteful inventories by reacting more effectively to customer demand and jointly planning product introductions and promotions (Soliman and Janz, 2004). 


\section{Literature REVIEW}

The IOISs has also been used to link pharmaceutical wholesalers and pharmacies in the Republic of Ireland and Australia, respectively, to create efficiency in ordering and delivery processes between the wholesalers and pharmacies (Bekking, 2004). In Kenya, IOIS is found in the banking industry, where the IOIS allows internet banking to take place (Gikandi and Bloor, 2012), mobile banking service (Nyangosi and Arora, 2009) and in electronic commerce (Magutu et al., 2011). By electronically linking organizations together, IOIS enables them to exchange business information, which makes them gain competitive advantage by increasing their bargaining power, and by raising the switching costs of trading partners (Johnston and Vitale, 1988). It also enhances organizational quality and timeliness of information and improves efficiency (Kaefer and Bendoly, 2000) and it also enables entire supply chains to reduce wasteful inventories by reacting more effectively to customer demand and jointly planning product introductions and promotions (Soliman and Janz, 2004). From a customer's perspective, the IOIS enables organizations to be more responsive to customer's orders, which improves the relationship with its business partners. From a broad view, the IOIS benefits are categorized into operational, managerial and strategic benefits (Rahim and Kurnia, 2004). Differing IOIS benefits are realized depending on the way the IOIS technology has been implemented in an organization. Operational benefits are directly influenced by IOIS integration with back-end systems and IOIS transactions ratio. Managerial benefits are influenced by strong cooperation from the business partners, and strategic benefits are realized when appropriate changes in relevant business processes are introduced in conjunction with IOIS adoption (Rahim and Kurnia, 2004). However, for an organization to realize these benefits, a strong support from the senior management in the adopting organization is required because they must allocate necessary resources, facilitate integration process changes and take the initiative to secure cooperation from the trading partners with which to establish electronic relationships. The need for IOIS adoption cannot be over-emphasized, since business competition has shifted from the simple firm to firm model, to competition between extended supply chain networks that are achieved by IOIS implementation. In reference to the institutions of higher learning, the Kenya Government has recognized the contribution of ICTs in the social and economic development of the nation. As a result, an ICT policy was developed to provide affordable infrastructure to facilitate dissemination of knowledge and skill through e-learning platforms in order to create the awareness of the opportunities offered by ICT as an educational tool in the education sector, through the sharing of e-learning resources between institutions (Republic of Kenya, 2006). Electronically linking universities together or with other organizations through the IOIS enables the universities to share electronic services such as e-learning, e-library, e-research and other electronic services (eservices). In the twenty first century education system that is ever changing with changes in technologies used to deliver the teaching materials, the need for IOIS adoption in the universities in Kenya is exacerbated by the fact that university students are now increasingly demanding for advanced methods of information acquisition, manipulation and application, and they show active preference for universities with greater access to Information System (IS) based resources (Adogbji and Akporhonor, 2005). Hence, universities that adopt the IOIS gain competitive advantages over the non-adopters.

\subsection{Research motivation}

Several studies conducted in the past to establish the technological factors influencing the adoption of IOIS have focused on developed countries, with limited studies being done for developing countries. The findings of these studies do not have a common agreement on 
factors influencing IOIS adoption in organizations (Almaxighi, 2009). Little research has been done to establish the technological factors that determinants IOIS adoption in Kenya (for example, see Gikandi and Bloor, 2010; Macharia and Nyakwende, 2010; Magutu et al., 2011).

In the institutions of higher learning, the use of internet based systems such as the IOIS are still in their early stages in developing countries like Kenya, and many issues regarding their adoption have not been fully addressed (Macharia and Nyakwende, 2010). Kashorda, Waema, Omosa and Kyalo (2006) found out that higher education institutions were not yet ready to effectively use Information and Communication Technology (which is the underlying infrastructure of the IOIS) in teaching, research and management of these institutions, and the factors that influence these institutions to embrace the ICT and its related innovations are not yet established.

The government of Kenya is conscious of the benefits that can be realized through IOIS adoption in institutions of higher learning (mainly the universities), and as such, has developed an Information and Communication Technology (ICT) policy that would help to establish networks for sharing training resources and developing strategies to support research and innovation in Kenya (Republic of Kenya, 2006). The implementation of this policy can be achieved through the adoption of the IOIS in the institutions of higher learning in Kenya. Therefore, this study investigated the relationship between technological factors and IOIS adoption in the universities in Kenya.

\subsection{Research Hypothesis}

This study collected and analyzed data to test the following research hypotheses:

$H \mathrm{O}_{1}$ : Availability of Internet factors had no relationship with IOIS adoption by universities in Kenya.

$\mathrm{HO}_{2}$ : Security of information sent over the IOIS link factors had no relationship with IOIS adoption by universities in Kenya.

$\mathrm{HO}_{3}$ : Complexity of IOIS technology factor had no relationship with IOIS adoption by universities in Kenya.

$\mathrm{HO}_{4}$ : Perceived cost of IOIS factor had no relationship with IOIS adoption by universities in Kenya.

\subsection{Research Framework}

Figure 1 presents the research framework examined in this study, which represents an integration of the four independent variable that are hypothesized to influence the adoption of the IOIS, which is the dependent variable.

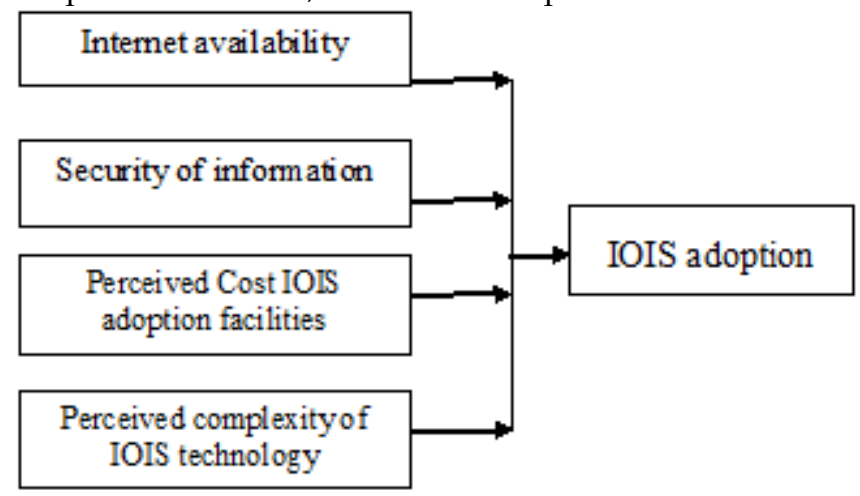

Figure 1: Research framew ork 


\section{Research Methodology}

The study used a combination of cross-sectional descriptive survey and explanatory research design. A descriptive research gives a thorough and accurate description survey by determining the "how" or "why" the phenomena came into being, and also what is involved in the situation. This is achieved by portraying an accurate profile of the events and situations (Robson, 2002), which Sunders et al. (2007) considered as an extension of, or forerunner to an explanatory research.

On the other hand, an explanatory study goes beyond description and attempts to explain the reasons for the phenomena that the descriptive study only observed (Cooper and Schindler, 2003) by seeking to establish a casual relationship between variables (Sunders et al., 2007). Therefore, a descriptive study would look at what is going on, while an explanatory study seeks to explain why it is going on (Sekaran, 2003). The researcher uses theories or hypothesis to account for the forces that caused a certain phenomenon to occur (Cooper and Schindler, 2003). A cross-sectional study seeks to measure the relationship of variables at a specified time, either to describe the incidence of a phenomenon or how variables are related (Sunders et al., 2007. The population of interest (universities in Kenya) was thoroughly investigated in their places of operation so as to freely give more information without the manipulation of unfamiliar environments in order to understand the factors that influence IOIS adoption in these institutions of higher learning.

\subsection{Theoretical Framework of the Model}

The factors influencing the adoption of IOIS in this study were determined using the logistic model, also known as logit model. The model calls for the analysis and prediction of a dichotomous outcome. Traditionally, this could have been addressed by either ordinary least squares (OLS) regression or linear discriminant function analysis. However, both techniques were found to pose challenges in handling dichotomous outcome due to their strict statistical assumptions such as linearity, normality and continuity for OLS regression, and multivariate normality with equal variances and covariances for discriminant analysis (Cabrera, 1994; Lei and Koehly, 2000). An alternative model that could have been used was the linear probability model or the probit model. However, the logit model was used in this study since it is easier to use.

\subsection{Model specification}

The logit model used in this study is specified as follws:

$$
\ln \left[\frac{P_{i}}{1-P_{i}}\right]=Z=X B+u=\beta_{0}+\beta_{1} X_{i 1}+\beta_{2} X_{i 2}+\ldots+\beta_{k} X_{i k}+u_{i}
$$

Where:

$$
X_{i 1} \ldots X_{i k i} \text { are the explanatory variables }
$$

$\beta_{1}-\beta_{\mathrm{k}}$ are the coefficients from the log of the odds ratio function.

$\mu=$ a vector of random terms

\subsection{Definition and Measurement of Variables}

The independent variables stipulated in the empirical model are categorized into organization factors, inter-organization factors, technological factors, environmental factors, perceived benefits factors and perceived cost factors. They are operationalized and hypothesized to influence IOIS adoption positively, negatively or indefinite as depicted in Table 3.1. 
Engineering International, Volume 1, No 1 (2013)

Table 1.1: Operationalization and Measurement of Variables and Hypothesis

\begin{tabular}{l|l|l|l|l} 
Category & $\begin{array}{l}\text { Variable } \\
\text { Definition }\end{array}$ & Operationalization & Measure & $\begin{array}{l}\text { Hypothesized } \\
\text { Direction of } \\
\text { the Variable }\end{array}$ \\
\hline $\begin{array}{l}\text { Dependent } \\
\text { variable }\end{array}$ & $\begin{array}{l}\text { IOIS } \\
\text { adoption } \\
(r)\end{array}$ & $\begin{array}{l}\text { An electronic link between } \\
\text { a university's } \\
\text { organizations' information } \\
\text { system and other } \\
\text { universities' or } \\
\text { organizations' information } \\
\text { systems is adopted, } \\
\text { otherwise not adopted }\end{array}$ & $\begin{array}{l}\text { Dum variable based } \\
\text { on the actual data: 1 if } \\
\text { not adopted }\end{array}$ & None \\
\hline
\end{tabular}

\begin{tabular}{|c|c|c|c|c|}
\hline \multicolumn{5}{|c|}{ Independent Variables } \\
\hline \multirow[t]{4}{*}{$\begin{array}{l}\text { Technologi } \\
\text { cal factors }\end{array}$} & $\begin{array}{l}\text { Internet } \\
\text { infra } \\
\text { structure }\end{array}$ & \begin{tabular}{|l|} 
Existing intemet \\
infras tructure stupporting \\
IOIS adoption by \\
organizations
\end{tabular} & $\begin{array}{l}\text { Extent to which the } \\
\text { existing internet } \\
\text { infrastructure } \\
\text { supporting IOIS } \\
\text { adoption by } \\
\text { organizations influence } \\
\text { the IOIS adoption on } 1-5 \\
\text { scale }\end{array}$ & Positive \\
\hline & Security & $\begin{array}{l}\text { The ability of the IOIS to } \\
\text { transaction information } \\
\text { without loss or } \\
\text { unatuthorized access }\end{array}$ & $\begin{array}{l}\text { Degree to which the } \\
\text { ability of the IOIS to } \\
\text { transact information } \\
\text { without loss or } \\
\text { unauthorized access } \\
\text { influence IOIS adoption } \\
\text { on } 1-5 \text { scale }\end{array}$ & Positive \\
\hline & Complexity & $\begin{array}{l}\text { Whether the IOIS } \\
\text { innovation is perceived as } \\
\text { difficult to understand } \\
\text { and use }\end{array}$ & $\begin{array}{l}\text { Dummy variable based } \\
\text { on the whether the IOIS } \\
\text { innovation is perceived } \\
\text { as complex or not, Yes: } \\
\text { If IOIS is complex No: if } \\
\text { IOIS is not complex }\end{array}$ & $\begin{array}{l}\text { Positive if not } \\
\text { complex }\end{array}$ \\
\hline & $\begin{array}{l}\text { Perceived } \\
\text { cost }\end{array}$ & $\begin{array}{l}\text { The market price of } \\
\text { software, hardware, } \\
\text { training, installation, } \\
\text { maintenance and Internet }\end{array}$ & $\begin{array}{l}\text { Dummy variable based } \\
\text { on the overall cost of } \\
\text { facilities supporting } \\
\text { IOIS adoption, } 1 \text {; if } \\
\text { affordable, } 0 \text { : if } \\
\text { unaffordable. }\end{array}$ & $\begin{array}{l}\text { Positive if } \\
\text { affordable }\end{array}$ \\
\hline
\end{tabular}

The study was conducted on universities in Kenya that are established under the Kenya Government universities' Act of Parliament 5 of 1985 (Republic of Kenya, 2010), and accredited by the Commission of University Education in Kenya. This included: public universities; constituent colleges of public universities that were established in 2007 by a Legal Order under the Act of the universities; chartered private universities that have been fully accredited by Commission for University Education in Kenya; constituent colleges of private universities; universities with Letters of Interim Authority from the Commission for University Education in Kenya to offer degree level of education while receiving guidance and direction from the Commission for University Education in order 
to prepare them for the award of Charter; and registered private universities that were offering university level education before the establishment of the Commission for University Education in 1985 and were issued with Certificates of Registration in 1989 by the Commission for University Education in Kenya.

\subsection{Target Population and Study Area}

The target population for this study was the universities Kenya. A list of the universities in Kenya was prepared as shown in Appendix D. The universities in Kenya were selected since they are known to have established links between themselves and the commercial banks to create an efficient procedure of fee payment by the students to the universities bank accounts, and the fee information is relayed electronically to the universities databases. Another factor that made the universities in Kenya to be considered in this study was due to the fact that Kenya Education Network (KENET) has put efforts to construct a terrestrial fiber-optic network that connects most institutions of higher learning, allowing them to integrate their facilities for the purpose of sharing resources (KENET, 2009). The universities that were considered to have adopted the IOIS are those that have established inter-organizational or inter-departmental IOIS integrated.

\subsection{Sampling Technique and Sample Size}

A census was done on the universities in Kenya. Since there were only 67 universities in Kenya, this number was too small to sample since the logit model estimation requires a minimum sample size of about 50 samples according to Agresti (2007). In addition, a census was considered as being able to allow the researcher to collect data from all the categories of the universities in Kenya.

\subsection{Data Collection Instruments}

The study made use of both the primary and secondary data. The secondary data was collected by conducting a detailed review of various literatures such as strategic plan, research and training plans and reports of the various universities. This was expected to reveal factors that influence IOIS adoption in these institutions. Primary data was collected by use of semi-structured questionnaire as used by Ssewanyana and Busler (2007). The use of semi-structured questionnaire was deemed necessary to enable the researcher to collect both qualitative and quantitative data. Semi-structured questionnaire and interviews were administered to the ICT managers of each university.

\subsection{Reliability Tests}

In this study, Cronbach's Alpha, which is a reliability test that indicates how well items in a set are positively correlated to one another, was used to measure internal consistency. As stated by Straub (1989), high correlations between alternative measures or large Cronbach's Alphas are usually signs that the measures are reliable. Cronbach's Alpha was computed in terms of the average interconnections among the items measuring the concept, and the closer the measure was to 1, the higher the internal consistency reliability (Independent variables on the dependent variable). Generally, reliabilities of 0.7 and over are considered acceptable as done by Muathe, Wawire and Ofafa (2010). The actual value for Cronbach's alpha realized in this study indicated a high level of internal consistency for the scale used.

\subsection{Validity Tests}

A pilot test was carried out with tertiary institutions to test the data collection instruments before the main survey. This enabled the researcher to check the validity of the data collection instruments and estimate with some accuracy the average completion time. The tertiary institutions in the pilot study were not included in the final sample. To complement the pilot test, this study made use of expert opinion to attest the content 
validity of the instrument (Straub, 1989). The feedback was used to improve the data collection instruments by eliminating any ambiguities and inadequate terms.

\subsection{Data Collection Procedure}

Data was collected over a period of four months. First, the researcher sought permission from Kenyatta University to start the process of collecting data which was granted. Afterwards, the researcher recruited and trained five research assistants to enable quick and timely collection of data. Before commencing data collection, the researcher sought an appointment with the ICT managers of the target organizations under study, after which the research assistants proceeded to self-administer questionnaires to the managers and staff involved in the IOIS transactions in the organizations, under the supervision of the researcher. The researcher administered the interviews to the ICT managers and the staff of the universities. The interviews were audio-taped and transcribed to ensure that the data was collected and used accurately.

After collecting data, it was edited to check for completeness, consistency and reliability. Afterwards, the data was transferred to the STATA for analysis.

\subsection{Data Analysis and Reporting}

The first step involved coding the responses in the coding sheets by transcribing the data from questionnaire by assigning characters symbols (numerical symbols). This was followed by screening and cleaning of data to make sure there were no errors. Afterwards, data was analyzed based on the objectives of this study. The quantitative data was analyzed using descriptive statistics such as frequency distributions, mean and percentages. Open-ended questions was analyzed by first identifying themes or topics such as ideas, concepts, terminologies, behaviors or phrases used, then organize these themes into coherent categories that summarize and bring meaning to the text as suggested by Ratcliff (2002). The binomial logit model was used for empirical analysis, to draw inference about the population.

\section{Results and Discussion}

\subsection{Descriptive statistics}

\subsubsection{Response Rate}

The overall response rate from both the public and private universities in Kenya is presented in Table 2, before providing analysis based on the research objectives of this study.

Table 2: Distribution of respondents in each sampled university

\begin{tabular}{|l|c|c|c|}
\hline Type of Universities & Frequency & Percentage & Valid Percentage \\
\hline Public universities & 7 & 10 & 15 \\
\hline Public universities constituent colleges & 19 & 28 & 40 \\
\hline Chartered private universities & 13 & 19 & 28 \\
\hline Registered Private universities & 2 & 3 & 4 \\
\hline $\begin{array}{l}\text { Private universities with letter of } \\
\text { interim authority }\end{array}$ & 6 & 9 & 13 \\
\hline Total & $\mathbf{4 7}$ & $\mathbf{6 9}$ & $\mathbf{1 0 0}$ \\
\hline Missing & 21 & 31 & \\
\hline Total & $\mathbf{6 8}$ & $\mathbf{1 0 0}$ & \\
\hline
\end{tabular}

As presented in Table 2, the percentage of the total number of respondents from the private universities (Chartered private universities, Registered Private universities and Private universities with letter of interim authority) was 39 per cent, which was lower 
compared to percentage of the total number of respondents from the public universities and the public universities constituent colleges, which was 50 per cent. The total response rate was 89 per cent, which compares well with the response rate of 70 per cent recommended by Yun and Trumbo (2008. The response rate depicted in Table 4.1 could be explained by the nature of the sensitivity of the information sought from respondents.

\subsubsection{LEVEL OF IOIS ADOPTION BY UNIVERSITIES IN KENYA}

The level of IOIS adoption by universities in Kenya is summarized in Table 3.

Table 3 Level of IOIS adoption in the Level of IOIS adoption in the universities in Kenya

\begin{tabular}{|l|c|c|c|}
\hline IOIS & Frequency & Percentage & Valid Percentage \\
\hline Adopted & 8 & 11 & 17 \\
\hline Not adopted & 39 & 58 & 83 \\
\hline Total & $\mathbf{4 7}$ & $\mathbf{6 9}$ & $\mathbf{1 0 0}$ \\
\hline Missing & 21 & 31 & \\
\hline Total & $\mathbf{6 8}$ & $\mathbf{1 0 0}$ & \\
\hline
\end{tabular}

It can be observed from Table 3, that $83 \%$ of the respondent indicated that their universities had not adopted the IOIS, while $17 \%$ had adopted. This shows that the IOIS adoption is low in the universities in Kenya, as justified in the reviewed literature. This finding supports Kashorda and Waema (2009) study, which found that universities in Kenya are still at low levels of network access.

\subsubsection{IOIS TECHNOLOGICAL FACTORS}

The third objective of this study was to investigate the influence of IOIS technological attributes on IOIS adoption by universities in Kenya. Among the technological factors that were considered included: technological support infrastructure necessary for IOIS adoption; security of information sent over the IOIS link; and complexity of the IOIS technology.

\subsubsection{Technological Support Infrastructure Necessary for IOIS Adoption}

Technological support infrastructure necessary for IOIS adoption, mainly the availability of internet connection that is used to link the organization in an IOIS cluster, is an integral factor that is expected to influence IOIS adoption in an organization. Table 4 summarizes perception of the respondents with regard to the availability of internet connection that was reliable and fast to motivate a university to adopt the IOIS.

Table 4 Availability of Internet connection that was reliable and fast

\begin{tabular}{|l|c|c|}
\hline Availability of internet connection & Frequency & Percent \\
\hline Strongly disagree & 17 & 36 \\
\hline Disagree & 19 & 40 \\
Uncertain & 2 & 4 \\
Agree & 7 & 15 \\
Strongly agree & 2 & 5 \\
\hline Total & 47 & 100 \\
\hline
\end{tabular}

Whereas $76 \%$ of the respondents disagreed that the available internet connection was reliable and fast to motivate their university to adopt IOIS, $20 \%$ of the respondents were of the opinion that the availability of internet connection that was reliable and fast motivated their university to adopt the IOIS. This finding explains the fact that availability of internet connection that is reliable and fast is able to motivate an organization to adopt the IOIS. The findings are supported by Kashorda et al. (2006), who found that the state of internet connection and speed in the universities in Kenya was so poor to an extent that $75 \%$ of the students considered cyber 
cafés to provide better speeds than the campus networks. They found that all of the users considered the internet speeds to be frustrating and slowing down their academic work.

\subsubsection{Security Guarantee of Information sent over the Internet}

The entire purpose of adopting IOIS is to transact information between organizations that have established an electronic link between themselves. Given that the IOIS link mainly uses the internet, the main concern is the internet security. The security guarantee of information sent over the internet from unauthorized access, theft or modification is crucial and is expected to motivate an organization to adopt the IOIS. Table 5 summarizes the perception of the respondents in terms of security guarantee of information transmitted over an IOIS link motivating a university to adopt the IOIS.

Table 5 Security guarantee of information sent over internet

\begin{tabular}{c|c|c|} 
Security guarantee of information & Frequency & Percentage \\
\hline Strongly disagree & 19 & 40.4 \\
\hline Disagree & 15 & 31.9 \\
\hline Uncertain & 7 & 14.9 \\
\hline Agree & 3 & 6.4 \\
\hline Strongly agree & 3 & 6.4 \\
\hline Total & 47 & 100
\end{tabular}

From Table 5 it can be observed that $72 \%$ of the respondents indicated that there was no security guarantee of information sent over the IOIS link, while $13 \%$ were in agreement that security guarantee of information sent over the IOIS link motivated them to adopt the IOIS. The findings reveal that the failure of most universities to adopt IOIS was owing to the fear of their confidential information being accessed by unauthorized persons rather than by universities/organizations in the IOIS cluster.

These findings are in line with the study of Gikandi and Bloor (2009), who found that internet security concerns was a hindrance to the adoption of electronic banking (a type of IOIS) in the commercial banks in Kenya. Magutu et al. (2011) also found that internet security was a barrier to the adoption of electronic commerce (a type of IOIS) in Kenya.

\subsubsection{Perception that the IOIS is Complex}

The perception that the IOIS technology is complex is likely to hinder an organization from adopting the IOIS. Figure 2 summarizes the perception of the respondents on the complexity of the IOIS.

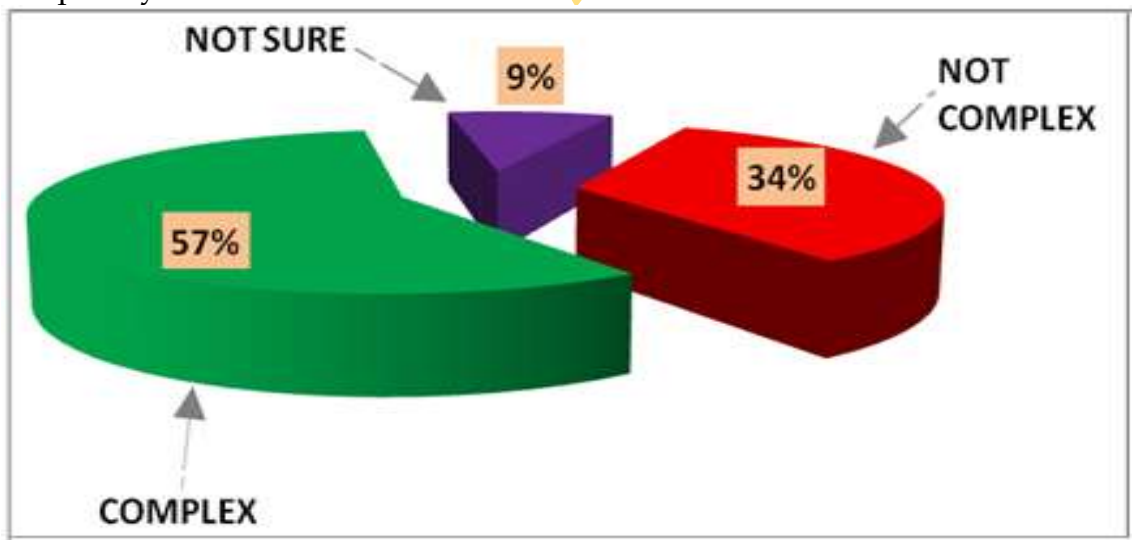

Figure 2 Perception on the complexity of IOIS technology 
As presented in Figure 2, a total of $57 \%$ respondents were of the view that the IOIS technology was complex to understand and use, while $34 \%$ were of the contrary opinion. This high percentage of respondents with the perception that the IOIS was complex could possibly explain the low level of IOIS adoption by universities in Kenya.

The study contributes towards the existing literature on IOIS technology adoption in Kenya. In particular, the study creates an understanding on the factors influencing IOIS adoption by universities in Kenya. This becomes a source of knowledge for the education institutions and other organizations in Kenya that will intend to adopt IOIS. The results of this study would also enlighten the policy makers in the education sector in Kenya on the possible policies that could be implemented to enhance IOIS adoption in the education sector so that the quality of teaching and research could be improved. Finally, the study will add knowledge to the existing empirical literature in information system, by informing about the factors that influence IOIS adoption in developing countries.

\subsubsection{Perceived Cost Factor}

The fourth objective of this study was to determine the influence of IOIS perceived cost factor on IOIS adoption in the universities in Kenya. The perceived cost factor considered in this study was the overall cost of the facilities necessary for IOIS adoption, which are likely to influence the decision of a university to adopt IOIS. Figure 3 summarizes the perception of the respondents with regard to the overall cost of the facilities that are necessary for IOIS adoption.

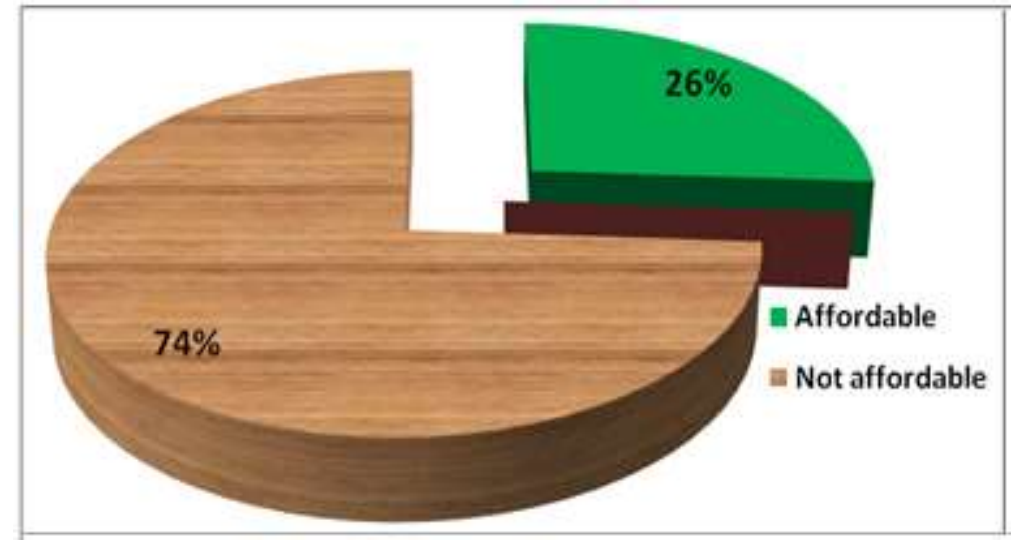

Figure 3 Perception of overall cost of IOIS

From Figure 4.4, it can be observed that $74 \%$ of respondents perceived the overall cost of IOIS to be unaffordable. This could be a part of the of the universities in the study that were found not to have adopted IOIS, On the other hand, $26 \%$ of the respondents perceived the overall cost of IOIS to be affordable. These could be universities that were stable financially, such as the large-sized public and private universities, and those with external financial sponsors. The universities that could have perceived IOIS to be unaffordable could have been the small public and more likely the newly accredited private universities by Commission for University Education, which had low student population and lacked the network facilities.

This finding is supported by Almazighi (2009), who found that large organizations with stable financial bases were more likely to adopt the IOIS technology. 


\subsection{Regression Results}

The explanatory variables that were considered included internet infrastructure support to adopt IOIS, perceived security of data offered by the IOIS technology, perceived complexity of the IOIS technology and perceived overall cost of the IOIS technology. The results of the logistic regression are presented in Table 6.

Table 6: IOIS Adoption Logistic Regression Results

\begin{tabular}{|c|c|c|c|c|c|c|}
\hline $\begin{array}{l}\text { Variable } \\
\text { Complex }\end{array}$ & $\begin{array}{c}\text { Coefficient } \\
-5.4103\end{array}$ & $\begin{array}{c}\text { Std. error } \\
2.3363\end{array}$ & $\begin{array}{c}\mathbf{Z} \\
-232\end{array}$ & $\begin{array}{r}\mathbf{P}>|\mathbf{Z}| \\
0.021\end{array}$ & $\begin{array}{c}95 \% \text { coefficient } \\
-9.9894 \\
\end{array}$ & $\begin{array}{l}\text { Interval } \\
-0.83129\end{array}$ \\
\hline Cost & -1.03201 & 0.38973 & -265 & 0.008 & -1.79588 & -026813 \\
\hline Security & -1.31135 & 1.44011 & -1.91 & 0.363 & -4.13393 & 1.51122 \\
\hline Internet & 4.17959 & 1.77972 & 2.35 & 0.019 & 0.69139 & 7.66779 \\
\hline \multicolumn{4}{|c|}{ 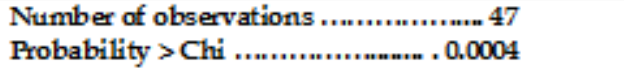 } & \multicolumn{3}{|c|}{ 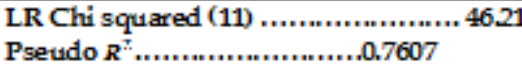 } \\
\hline
\end{tabular}

Log Likelihood (LR) test gave a value of 46.21 which was statistically significant at $1 \%$ level. This implies that the overall logit model that was estimated was statistically significant, that is, there was a significant relationship between the log of odds ratio and the explanatory variables. From Table 6, the Pseudo R squared of the regression was 0.76, which implies that the included variables explained only 76 per cent of the variations in the adoption of the IOIS among the universities studied. The remaining 24 per cent was explained by other explanatory variables not included in the model.

The coefficient of the perceived complexity of the IOIS technology was negative (-5.4103) and significant $(p=0.021)$. This implied that the adoption of IOIS by the universities in Kenya is inversely related to the complexity of the IOIS technology. This finding is in conformity with the argument of Dykeman (1997) that operations complexity of Internet Bases Information Systems (IBIS) technology are issues of concern that are unique to the environment of conducting electronic commerce (EC) over the Internet and can hamper its adoption.

The coefficient of perceived cost of the facilities necessary for IOIS adoption was negative ($1.03201)$ and significant $(p=0.008)$ this implied that the IOIS adoption was inversely proportional to the perceived cost of the facilities necessary for its adoption. This means that the universities that perceive the cost of the facilities necessary for IOIS adoption to be unaffordable are less likely to adopt the IOIS that the universities that perceive the cost of the facilities necessary for IOIS adoption to be affordable. This contrary to the findings of Rahim et al. (2007) who found out that the cost of IOIS adoption was hindrance to its adoption.

The positive $(4.17959)$ and significant $(p=0.019)$ coefficient of Internet infrastructure was as expected in this study. It means that in the universities where the Internet infrastructure is fast and reliable the likelihood of IOIS adoption is higher than in the universities where the Internet infrastructure is slow and unreliable. These finding are in agreement with the findings of Soliman and Janz (2004) who found out that the Internet is a promising platform that allows technological adoption that allow exchange of information along the business channels, and Vadapalli and Ramamurthy (1997) who found the internet to be a key factor for quick diffusion of technological innovations among organizations. However, Lastly, the coefficient of the perceived security of the IOIS technology did not have the expected positive sign but a negative sign, and it was not significant at 1 per cent, 5 per cent or 10 per cent levels of significance. This could be attributed to the fact that the majority of information transacted between universities are educational in nature, which does not call for serious security address. 


\section{Conclusion}

The study found out that there is significant relationship between IOIS adoption and IOIS technological factors. Two technological factors (perceived cost and complexity of IOIS) were found to hinder IOIS adoption in the universities in Kenya. However, one factor (availability of Internet infrastructure) was found to motivate IOIS adoption in the universities in Kenya, while one factor (perceived security of data sent over the IOIS link) was found not to have any relationship with the IOIS adoption in the universities in Kenya.

For the country to realize the national economic goals stipulated in Kenya Vision 2030, there is need for the education sector, and mainly the institutions of higher learning such as the universities in Kenya, to provide quality teaching and research as a means of achieving a high standard of education. This can be realized through the adoption of the IOIS by the universities in Kenya. The significance of the current study is that it presents new insights on the relationship between the technological factors and IOIS adoption by universities in Kenya, which can be used by policy makers in the universities in Kenya to suppress the factors that hinder IOIS adoption and emphasize on the factors that motivate IOIS adoption. This would encourage the adoption of IOIS in the universities in Kenya.

Since the internet is mainly the media used to link the universities together, the universities in Kenya should, through the Ministry of Information and Communication and other nongovernmental bodies such as Kenya Education Network (KENET) should ensure that universities enjoy a subsidized cost of internet connection that is reliable and fast. This would enable the universities that cannot afford to pay for a high cost of internet connection to have internet connection in their universities. This will consequently enable the universities to adopt the IOIS due to the availability of a reliable and fast internet connection. The universities in Kenya should jointly enforce standards and uniformity on the Information Technology (IT) degree offered in the universities in Kenya to ensure that they are of high quality. This will ensure that the students who graduate with such degrees will have adequate skills and knowledge in IOIS adoption, and will not view it as a complex technology. This is necessary since the complexity of IOIS was found to be significant in hindering the IOIS adoption in the universities in Kenya.

\section{REFERENCE}

Adogbji, B., and Akporhonor, A. B. (2005). The Impact of ICTs (internet) on research and studies; The experience of Delta state university students in Abraka Nigeria. Library HiTech News, 1 (10), 17-21.

Agresti, A. (1990). Categorical Data Analysis. John Wiley and Sons, New York, 24-32.

Alimazighi, Z. and Bouchbou,T K. (2009). A framework for identifying the critical factors affecting the decision to adopt and use inter-organizational information systems. International journal of human and social sciences 4:7 2009, 509-511.

Cabrera, A. F. (1994). Logistic regression analysis in higher education: An applied perspective. Higher Education: Handbook of Theory and Research, Vol. 10, 225-256.

Cooper, D. and Schindler, S. (2003). Business Research Methods, $7^{\text {th }}$ Edition, Boston, McGrawHill.

Gikandi J.W. and Bloor C. (2010). Adoption and effectiveness of electronic banking in Kenya. Electronic Commerce Research and Applications 9 (2010), 277-282.

Johnston, H.R., and Vitale, M.R. (1988). Creating Competitive Advantage with Interorganization Information Systems. MIS Quarterly (12: n), June 1988, 153-165.

Kaefer F. and Bendoly E. (2000). The adoption of electronic data interchange. A model and practical tool for managers. Decision Support Systems 30, 23-32. 
Engineering International, Volume 1, No 1 (2013)

Kashorda M., Waema T. (2009). E-Readiness Survey of East African Universities. Kenya Education Network (KENET), 13-37.

Kashorda M., Waema T. , Omosa M. and Kyalo V. (2006). E-Readiness Survey Of Higher Education Institutions in Kenya. Kenya Education Network Trust, 16-32.

Lei, P.W., and Koehly, L. M. (2000, April). Linear discriminant analysis versus logistic regression: A comparison of classification errors. Paper presented at the annual meeting of the American Educational Research Association. New Orleans, LA.

Macharia J. and Nyakwende E. (2009). Factors affecting the adoption and diffusion of Internet in higher educational institutions in Kenya. Journal of Language, Technology and Entrepreneurship in Africa Vol.1(2)2009: 1-3

Magutu P.O., Mwangi M., Nyaoga B.R., Ondimu G.M., Kagu M., Mutai K., Kilonzo H., Nthenya P. (2011). E-Commerce Products and Services in the Banking Industry: The Adoption and Usage in Commercial Banks in Kenya. Journal of Electronic Banking Systems. Vol. 2011, 1-8.

Nyangosi, R. and Arora J.S. 2009. Emergence of Information Technology in the Kenyan banking Sector: An empirical study. International Journal of Electronic Finance 3(2), 6-12.

Rahim M.M. and Kurnia S. (2004). Factors Influencing Benefits of Inter-Organizational Systems (IOIS) Adoption. San Diego international systems conference, 14-16 July, San Diego, USA, 1-5.

Republic Of Kenya (2006). Electronic Learning. National Information and Communications Technology (ICT) Policy. Ministry Of Information \& Communications January 2006, 5.

Saunders, M;Lewis.P; Thonhill, A. (2007).Research methods for business students. $3^{\text {rd }}$ edition, Great Britain, prentice hall.

Soliman K. S. and Janz B. D (2004). Inter-organization Information Systems. Exploring an Internet-Based Approach. Information and Management Volume 41, Issue 6, July 2004, 697706.

Ssewanyana J. and Busler M. (2007). Adoption and usage of ICT in developing countries: Case of Ugandan firms. International Journal of Education and Development using Information and Communication Technology (IJEDICT), 2007, Vol. 3, Issue 3, pp. 49-59. Silverman, P.B. (1990). Information revolution in the Pacific rim: Implications for the '90s," Pacific Telecom Conference, Honolulu, Hawaii, 1990, 106-117.

Vadapalli, A. and Ramamurthy, K. (1997). Business use of the Internet: an analytical framework and exploratory study," International Journal of Electronic Commerce, Vol. 2, No. 2, Winter 1997-98, pp. 71-94.

\section{Why Open Access ???}

"In the traditional publishing model, readers have limited access to scientific papers; authors do not have copyright for their own papers, and cannot post their papers on their own websites, which presents a significant barrier to the sharing of knowledge, as well as being unfair to authors. Open access can overcome the drawbacks of the traditional publishing model and help scholars build on the findings of their colleagues without restriction"

$\mathrm{ABC}$ Journals is a unique forum to offer open access to all of its articles.

Now ABC Journal's portfolio is over nine journals, which publish both online and in print. 